\title{
PENGARUH PELATIHAN BENCANA DAN KESELAMATAN KERJA TERHADAP RESPONS PERSEPSI MAHASISWA PRODI ILMU KESEHATAN MASYARAKAT
}

\author{
Tri Niswati Utami ${ }^{1}$, Meutia Nanda ${ }^{2}$ \\ ${ }^{1,2}$ Fakultas Kesehatan Masyarakat \\ Universitas Islam Negeri Sumatera Utara Medan \\ Emal: triniswatiutami@ uinsu.ac.id; meutianandaumi@gmail.com
}

\begin{abstract}
Disasters are categorized as 2, namely natural disasters and non-natural disasters. Natural disasters such as earthquakes, tsunamis, floods, landslides, fires. Non-natural disasters such as accidents at work, accidents at home, schools, boarding schools, campuses, shopping, roads and so forth. The aim of the study: to analyze the effect of disaster and work safety training on students' perceptions of knowledge and attitudes toward disaster risk Methods: research desain is quasi eksperiment with one group pre and post test desain. The sample is a student of the public health study program at the State Islamic University of North Sumatra Medan. Data analysis with t-test. The results of the study: there was a significant effect of disaster and safety training on perceptual responses of student knowledge p-value of $0.0001<0.05$. There is a significant effect of disaster and occupational safety training on the perceptual responses of students' attitudes of p-value of $0.0001<0.05$. Knowledge and attitude cannot be separated. These two things are interconnected, with the knowledge of earthquake disaster preparedness it will affect one's attitude when a disaster occurs. The training stimulus builds a positive perception response. Disaster training is more effective and acceptable when combined with work safety and health material in the campus environment so that respondents are more easily accepted. Conclusion: Modification of disaster management and occupational health safety training is more easily understood by respondents. So that it effectively changes the respondents' knowledge and attitudes. The success of training as a means of changing knowledge and attitudes is determined by internal and external factors. Suggestion: implementation of safety and health at the university level needs to be done, to minimize the risk of accidents.
\end{abstract}

Keywords: disaster training, occupational safety, and health, perceptual responses, knowledge, attitudes.

\section{PENDAHULUAN}

Bencana gempa bumi di Aceh pada tahun 2004 mengakibatkan 165.708 jiwa meninggal, 37.03 jjiwa hilang dan 100.000 jiwa menderita luka berat dan ringan. Mayoritas korban jiwa adalah anak dan usia lanjut (Iskandar, 2010). Menurut Rudianto berdasarkan hasil penelitian menjelaskan pendekatan soft power membangun kesiagaan masyarakat melalui sosialisasi dan pemberian informasi, baik edukasi atau pelatihan. Hard power adalah upaya menghadapi bencana melalui pembangunan fisik seperti membangun sarana komunikasi, tanggul, mendirikan dinding beton, mengeruk sungai dan sebagainya (Rudianto, 2012).

Bencana non alam seperti: kecelakaan di tempat kerja, kecelakaan di rumah, sekolah, pesantren, kampus, tempat 
perbelanjaan, jalan dan lain sebagainya. Kecelakaan secara terminologi adalah kejadian yang tidak diduga, yang terjadi secara tiba-tiba. Tidak sedikit kasus kecelakaan di sekolah, pesantren atau kampus terjadi. Kejadian Tidak Diharapkan (KTD) tersebut antara lain: terpeleset di kamar mandi atau jatuh dari tangga yang mengakibatkan cedera, lecet, patah tulang, terkilir, keseleo, jatuh dari kenderaan, tabrakan saat parkir di kampus dan lain sebagainya.

Masalah ini terjadi karena penerapan keselamatan dan kesehatan di sekolah dan pesantren belum menjadi sebuah keharusan. Penerapan Budaya Keselamatan dan Kesehatan Kerja (Budaya K3) pada level Universitas, belum seperti yang diharapkan. Data berikut menjelaskan bahwa masih banyak perguruan tinggi yang belum menerapkan budaya keselamatan dan kesehatan kerja. Setyaji dalam tulisannya memaparkan: budaya keselamatan dan kesehatan yang saat ini gencar diterapkan diberbagai aspek pekerjaan di negeri ini nampaknya masih jauh diterapkan di kampus. Kampus Universitas Indonesia belum maksimal mengimplementasikan budaya Keselamatan dan Kesehatan Kerja (K3) (Setyaji, 2013).

Universitas Gajah Mada (UGM) telah menerapkan sistem SHE (Safety Health and Environment). Mengingat beberapa kasus kejadian kecelakaan pernah terjadi di kampus UGM. Penerapan sistem SHE merupakan mekanisme darurat dalam sistem bencana, juga upaya menjaga keselamatan dan kesehatan seluruh tenaga pendidik, tenaga kependidikan, mahasiswa dan pihak lain yang terkait di wilayah Universitas Gajah Mada (Satria, 2015).

Sistem manajemen K3 di Fakultas Kesehatan Masyarakat Universitas X belum dapat dilaksanakan. Kendala utama adalah ketersediaan tenaga ahli K3. Hasil penelitian berdasarkan wawancara menemukan bahwa belum memiliki kebijakan K3 secara tertulis, tertanggal, ditandatangani, jelas menyatakan tujuan dan komitmen untuk memperbaiki kinerja K3. Menurut informan, kebijakan K3 akan ditetapkan secara terpusat pada satu universitas, sehingga kebijakan K3 di FKM Universitas $\mathrm{X}$ sampai saat ini belum ditetapkan (Atikah; Ida Wahyuni; Ekawati, 2016).

Program studi ilmu kesehatan masyarakat yang berada dibawah Fakultas Kesehatan Masyarakat Universitas Islam Negeri Sumatera Utara, berlokasi di Jalan IAIN no 1 Medan pernah terjadi Kejadian yang Tidak Diharapkan (KTD) seperti: mahasiswa jatuh dari sepeda motor, pejalan kaki diserempet sepeda motor, petugas kebersihan tersenggol mobil/motor pada saat bekerja, mahasiswa tersenggol mobil saat berjalan menuju kampus. Berdasarkan observasi peneliti, kejadian ini terjadi karena belum ada rambu keselamatan yang 
mengatur pejalan kaki, pengendera sepeda motor, mengemudi mobil dan pengaturan parkir. Bahkan ditemukan posisi parkir kenderaan yang tidak pada tempatnya.

Permasalahan bencana serta penerapan keselamatan dan kesehatan kerja di lingkungan kampus belum mendapat perhatian, sehingga risiko kecelakaan dan penyakit pada dosen, tenaga kependididikan, mahasiswa, petugas kebersihan, pengunjung kampus masih terjadi. Atas dasar inilah perlu dilakukan penelitian di program studi ilmu kesehatan masyarakat, sehingga Kejadian yang Tidak Diharapkan (KTD) dapat dicegah dan tidak terjadi. Disisi lain sosialisasi dan pelatihan bencana perlu diterapkan untuk meminimalisir risiko yang dapat menimbulkan korban akibat bencana.

Bencana sesuatu yang tidak dapat diduga dan tidak dapat diprediksi, sehingga perlu ketenangan dalam menghadapi bencana. Kesiapsiagaan dalam menghadapi mencana diharapkan dapan mengurangi dampak bencana. Pelatihan siaga bencana gempa bumi dapat dilakukan dengan model praktik langsung, meniru tindakan seperti saat terjadi gempa ketika sedang berada di sekolah (Daud, Sari, Milfayetty, \& Dirhamsyah, 2014).

Keberhasilan masyarakat dalam menghadapi bencana, ditentukan oleh kepemimpinan. Ketiadaan dan kelemahan pemimpin (otoritas pemerintah) menyebabkan kebingungan, kehancuran, kerugian dan malapetaka. Pemimpin harus mampu bertindak cepat, tanggap, tepat dan berani mengambil keputusan menjalankan instruksi (Kurniayanti, 2012). Budaya keselamatan dan ketahanan khususnya untuk anak sekolah dasar dan generasi muda, perlu dikembangkan melalui program pelatihan siaga. Pengalaman yang dirasakan masyarakat di Indonesia, pernah terjadi bencana besar seperti sunami di Aceh, yang menghilangkan jutaan korban jiwa dan harta benda (Daud dkk., 2014).

Menurut Kamus Besar Bahasa Indonesia (KBBI) respons adalah tanggapan, reaksi atau jawaban. Reaksi akibat rangsang ini diterima oleh panca indra. Selanjutnya respons dimanifestasikan (diwujudkan) dalam bentuk perilaku yang dimunculkan setelah dilakukan perangsangan. Respon dapat diamati, namun ada kalanya tidak dapat secara langsung diamati, karena dalam bentuk emosi, perasaan dan pikiran. Sikap yang dapat diamati, akan direfleksikan pada individu dan memberi warna pada tingkah laku dan perbuatannya.

Persepsi menurut asal kata berasal (dari bahasa Latin perceptio, percipio) adalah tindakan menyusun, mengenali, dan menafsirkan informasi sensoris guna memberikan gambaran dan pemahaman tentang lingkungan. Persepsi meliputi semua sinyal dalam sistem saraf yang 
merupakan hasil dari stimulasi fisik atau kimia dari organ pengindra. Seperti misalnya penglihatan yang merupakan cahaya yang mengenai retina pada mata, pencium yang memakai media molekul bau (aroma), dan pendengaran yang melibatkan gelombang suara. Persepsi bukanlah penerimaan isyarat secara pasif, tetapi dibentuk oleh pembelajaran, ingatan, harapan, dan perhatian. Persepsi bergantung pada fungsi kompleks sistem saraf, tetapi tampak tidak ada karena terjadi di luar kesadaran

Proses persepsi terjadi karena proses yang didahului oleh penginderaan. Rangsangan (stimulus) diterima oleh individu reseptor yaitu indera manusia penglihatan, pendengaran, rasa, raba atau penciuman. Alat indera inilah sebagai penghubung antara individu dengan dunia luarnya. Informasi tersebut kemudian diterima indera manusia, selanjutnya diorganisasikan dan diinterpretasikan sehingga individu mempunyai "makna" terhadap stimulus tersebut membangkitkan rasa kesadaran dan mengerti tentang apa yang diindera.

Perilaku manusia merupakan semua aktivitas yang dilakukan manusia yang dapat diamati seperti: berjalan, berbicara, menangis, tertawa, bekerja, kuliah, menulis, membaca, berfikir dan sebagainya. Dari uraian tersebut bisa disimpulkan bahwa perilaku manusia adalah semua kegiatan atau aktivitas manusia, baik yang diamati langsung, maupun yang tidak dapat diamati oleh pihak luar (Notoatmodjo, 2003). Menurut Skinner, bahwa perilaku merupakan respon atau reaksi seseorang terhadap stimulus atau rangsangan dari luar. Oleh karena perilaku ini terjadi melalui proses adanya stimulus terhadap organisme, dan kemudian organisme tersebut merespons, maka teori Skinner ini disebut teori "S-O-R" atau Stimulus - Organisme Respon.

Pada dasarnya bentuk perilaku dapat diamati, melalui sikap dan tindakan, namun demikian tidak berarti bahwa bentuk perilaku itu hanya dapat dilihat dari sikap dan tindakannya saja, perilaku dapat pula bersifat potensial, yakni dalam bentuk pengetahuan, motivasi dan persepsi. Bloom (1956), membedakannya menjadi 3 macam bentuk perilaku, yakni Coqnitive, Affective dan Psikomotor, Ahli lain menyebut Pengetahuan, Sikap dan Tindakan, Sedangkan Ki Hajar Dewantara, menyebutnya Cipta, Rasa, Karsa atau Peri akal, Peri rasa, Peri tindakan.

\section{METODE PENELITIAN}

Jenis penelitian ini quasi eksperiment (eksperimen semu) menggunakan rancangan penelitian one group pre test and post test design. Rancangan ini digunakan karena penelitian ini memberikan perlakuan dalam bentuk intervensi (pelatihan risiko bencana dan keselamatan kerja). 
Pengukuran pada subyek penelitian dilakukan 2 kali, satu kali pengukuran (pre test) sebelum diberikan perlakuan (treatment) dan pengukuran satu kali setelah diberikan perlakuan (post test) (Noor, 2013). Populasi penelitian ini adalah seluruh mahasiswa yang belajar di program studi ilmu kesehatan masyarakat. Mengingat keterbatasan waktu dan dana, penelitian ini menggunakan sampel. Penentuan besar sampel dengan teknik purposive sampling.

Analisis data dilakukan dengan cara: Analisis univariat. Data yang diperoleh kemudian ditabulasi dalam bentuk tabel distribusi frekwensi, dilanjutkan dengan analisis bivariat uji t paired menggunakan software SPSS versi 19 (Hastono, 2016).

\section{HASIL DAN PEMBAHASAN}

\section{Karakteristik Responden}

Berdasarkan uraian teori perilaku, bahwa perubahan perilaku bergantung pada individu, terkait dengan konsep ini penelitian ini mendapatkan data karakteristik responden seperti: jenis kelamin, umur, latar belakang pendidikan, dan suku disajikan pada tabel dibawah ini:

Tabel 1 Karakteristik Jenis Kelamin Responden Penelitian

\begin{tabular}{ccc}
\hline Jenis & $\begin{array}{c}\text { Frekwensi } \\
\text { (f) }\end{array}$ & $\begin{array}{c}\text { Persentase } \\
(\%)\end{array}$ \\
\hline kelamin & 5 & 16,7 \\
Paki-laki & 25 & 83,3 \\
\hline Jumpuan & 30 & 100 \\
\hline
\end{tabular}

Responden penelitian mayoritas jenis kelamin perempuan sebanyak 25 orang
$(83,3 \%)$ dan laki-laki sebanyak 5 orang $(16,7 \%)$. Responden penelitian adalah mahasiswa di Program Studi Ilmu Kesehatan Masyarakat, secara keseluruhan perbandingan mahasiswa di program studi adalah $1: 25$ orang.

Perbedaan jenis kelamin ini di program studi ilmu kesehatan masyarakat, berhubungan dengan bidang kesehatan lebih banyak diminati oleh kelompok perempuan. Berbeda dengan bidang ilmu teknik, lebih banyak diminati oleh kelompok laki-laki. Sesuai dengan teknik pengambilan sampel purposive sampling, berdasarkan kriteria inklusi salah satunya adalah bersedia menjadi responden dan mengikuti pelatihan hingga selesai. Jumlah responden laki-laki yang berdomisili di Medan dan bersedia mengikuti pelatihan hanya 5 orang, sehingga mendukung jumlah responden yang didominasi oleh perempuan.

Laki-laki lebih senang menggunakan waktu untuk mengakses internet, dibandingkan menggikuti kegiatan di kampus seperti pelatihan. Asumsi ini di dukung dengan penelitian yang dilakukan oleh Nur (2014) perbedaan jenis kelamin memengaruhi penggunaan media informasi. Penelitian tersebut menjelaskan bahwa responden dengan jenis kelamin laki-laki cenderung menggunakan internet untuk mencari informasi, game, dan meluangkan sedikit waktu untuk bersosial media. Sedangkan responden dengan jenis kelamin 
perempuan di usia tersebut hampir $100 \%$ menggunakan internet untuk bersosial media. Majunya tekhnologi untuk mengakses internet sekaligus menggunakan handphone lebih membuat responden di usia ini memilih mencari informasi, bersosial media sekaligus mencari hiburan melalui alat yang lebih praktis untuk digunakan (Nur, 2014).

Tabel 2 Karakteristik Umur Responden Penelitian

\begin{tabular}{ccc}
\hline $\begin{array}{c}\text { Umur } \\
\text { (Tahun) }\end{array}$ & Frekwensi (f) & $\begin{array}{c}\text { Persentase } \\
(\%)\end{array}$ \\
\hline 18 & 10 & 33,3 \\
19 & 15 & 50,0 \\
20 & 5 & 16,7 \\
\hline Jumlah & 30 & 100 \\
\hline
\end{tabular}

Tabel diatas memperlihatkan bahwa karakteristik responden berdasarkan umur, mayoritas berumur 19 tahun sebesar 15 orang (50\%). Rentang umur responden 18 20 tahun berarti bahwa selisih umur responden \pm 3 tahun

Tabel 3 Karakteristik Latar Belakang Pendidikan

Responden Penelitian

\begin{tabular}{lcc}
\hline $\begin{array}{l}\text { Latar } \\
\text { Belakang }\end{array}$ & $\begin{array}{c}\text { Frekwensi } \\
\text { (f) }\end{array}$ & $\begin{array}{c}\text { Persentase } \\
(\%)\end{array}$ \\
\hline Pendidikan & & \\
SMA & 18 & 60,0 \\
Pesantren & 3 & 10,0 \\
Madrasah & 2 & 6,7 \\
\hline Jumlah & 7 & 23,3 \\
\hline
\end{tabular}

Mayoritas responden penelitian mempunyai latar belakang pendidikan SMA sebanyak 18 orang (60\%). Latar belakang pendidikan memengaruhi pengetahuan seseorang. Penelitian sebelumnya tingkat pengetahuan pada anak Madrasah di sekolah yang sama namun berbeda tingkat kelasnya, mempunyai perbedaan dalam memahami konteks bahaya dan keselamatan di sekolah.

Perbedaan tingkat pengetahuan siswa pada survey pendahuluan menemukan bahwa: siswa kelas III Madrasah Ibtidaiyah dan kelas IV mempunyai pendapat yang berbeda tentang bahaya dan keselamatan di sekolah. Diantaranya $70 \%$ siswa menyatakan tidak tahu akan bahaya keselamatan di sekolah (Sandy, 2012).Dapat dijelaskan lebih lanjut dengan latar belakang pendidikan seperti SMA, SMK, Pesantren, Madrasah dipastikan mempunyai perbedaan dalam mengetahui, memahami keselamatan dan kesehatan di lingkungan sekolahnya. Sebagai contoh SMK (Sekolah Menengah Kejuruan), sebagai sekolah kejuruan untuk mencapai ketrampilan (skill) peserta didik kegiatan pembelajaran tidak hanya dalam tutorial dikelas tetapi juga menerapkan sistem pembelajaran praktik (praktikum) di laboratorium maupun lapangan.

Laboratorium merupakan tempat yang menyimpan potensi bahaya, baik laboratorium komputer, mekanik, biologi, fisika. Kimia, obat-obatan dan lain sebagainya. Untuk mencegah bahaya kecelakaan dan injury petugas laboratorium, memberikan tata tertib dan prosedur praktik atau menggunakan laboratorium. Berdasarkan hal ini, siswa mempunyai 
gambaran bahaya dan keselamatan di lingkungan sekolahnya, karena telah mendapat informasi sebelumnya dari sekolahnya pada masa yang lalu.

Demikian juga pendidikan SMA (Sekolah Menengah Atas) mempunyai beberapa laboratorium seperti: laboratorium Fisika, Biologi dan Kimia. Kegiatan praktik di SMA tidak sebanyak di SMK, tetapi berbekal pengalaman di sekolah sebelumnya pemahaman responden terhadap bahaya keselamatan di sekolah sudah ada.

Tabel 4 Karakteristik Responden Penelitian Berdasarkan Suku

\begin{tabular}{ccc}
\hline Suku & Frekwensi (f) & Persentase (\%) \\
\hline Batak & 12 & 40 \\
Melayu & 4 & 13,3 \\
Minang & 2 & 6,7 \\
Jawa & 12 & 40 \\
\hline Jumlah & 30 & 100 \\
\hline
\end{tabular}

Berdasarkan suku, responden penelitian mayoritas adalah batak (40\%), jawa 12 (40\%). Indonesia terdiri dari beragam suku, data Badan Pusat Statistik merilis pada 2010 yang menyebut ada 1.128 suku di Indonesia yang tersebar di lebih dari 17 ribu pulau. Keberagaman ini menjadikan Indonesia salah satu negara dengan budaya paling kaya. Di sisi lain, keberagaman juga dapat memicu konflik bila tak dijembatani dengan baik. Tempo mencatat beberapa tragedi di Indonesia yang bersumber karena perbedaan budaya. Konflik itu tak hanya menelan korban materi namun juga menghilangkan nyawa ratusan orang (Mardiana, 2017).

Keberagaman suku juga ditemukan pada mahasiswa di program studi Ilmu Kesehatan Masyarakat antara lain: Jawa, Sunda, Banten, Minangkabau, Batak Toba, Batak Pak Pak, Batak Simalungun, Batak Karo, Tapanuli Selatan, Melayu, Aceh dan Nias. Sosial budaya mempunyai pengaruh terhadap cara pandang dan pengetahuan seseorang.

Perbedaan suku ini menciptakan kekayaan bagi manusia untuk beradaptasi terhadap lingkungan sosial. Mahasiswa dapat belajar untuk beradaptasi, atau bahkan melakukan asimilasi dengan mahasiswa yang berbeda suku. Adaptasi adalah proses penyesuaian diri terhadap situasi atau kondisi yang baru. Penyesuaian diri sebagai tahap pembelajaran yang positif kepada mahasiswa.

Asimilasi merupakan proses sosial yang ditandai dengan usaha untuk mengurangi perbedaaan yang ada dianatara orang, kelompok di lingkungan mereka. Asimilasi juga merupakan usaha mempertinggi tindakan, sikap sebagai proses mental untuk memdapatkan tujuan dan kepentingan bersama (Mardiana, 2017). Beragam suku yang ada di program studi Ilmu Kesehatan Masyarakat, mengajarkan mahasiswa untuk saling mengenal sehingga menumbuhkan sikap menghargai dan menghormati perbedaan diantara mereka. 
Islam menyebutkan dalam Al Qur'an Surah Al Hujarat ayat 13.

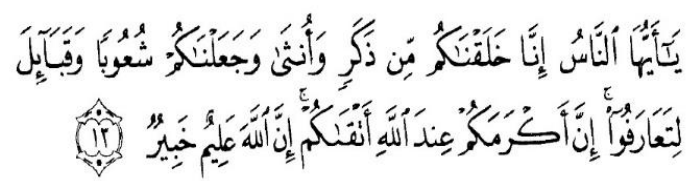

"Wahai manusia, sesungguhnya Kami menciptakan kamu dari seorang laki-laki dan seorang perempuan, serta menjadikan kamu berbangsa-bangsa dan bersuku-suku, supaya kaтu saling kenal mengenal. Sesungguhnya orang yang paling mulia di antara kamu di sisi Allah adalah orang yang paling bertakwa di antara kamu. Sesungguhnya Allah Maha Mengetahui lagi Maha Mengenal." (QS. Al-Hujurat [49]: ayat 13).

Menurut (Afif, 2016) tujuan Allah menciptakan manusia berbangsa dan bersuku, adalah manusia memahami perbedaan diantara mereka, mempunyai kecenderungan untuk saling membantu satu dengan lainnya. Manusia mempunyai tugas untuk mengenal hakikat diri mereka sendiri, sebagai makhluk yang akan berpencar di muka bumi, lalu membangun kebangsaan mereka. Munculnya perbedaan etnis di tengah manusia adalah Sunnatullah, dengan demikian akan muncul sinergi dan kecenderungan untuk saling membantu antara satu dengan lainnya.

Mempelajari budaya suatu suku akan memperluas khasanah berfikir seseorang, mengambil sisi positif dari suku tersebut. Memaksimalkan potensi tiap suku yang ada membuat manusia lebih fleksibel dan menjadi makhluk yang dinamis. Tujuan ini digariskan Allah kepada hambanya untuk saling menghargai sesama manusia dan antar suku. Hubungan ini akan terjalin apabila manusia dapat menggunakan komunikasi dengan baik. Tuntutan ini mengajarkan manusia untuk bersikap sopan dan santun. Apabila ini diterapkan dalam segala aktivitas manusia maka secara tidak langsung manusia dianjurkan untuk berbuat kebaikan dalam bergaul terhadap sesama manusia yang berbeda suku, bangsa maupun agama. Ini berarti mengajarkan manusia pada akhlak yang baik.

Setiap suku mempunyai aturan dan keyakinan dan tradisi yang berbeda. Seringkali tradisi ini dapat dijadikan panutan dalam memenuhi kebutuhan manusia baik dalam pertanian, peternakan, kelahiran, perkawinan maupun untuk mencari ikan di laut. Misal Banyak suku bangsa yang tidak dapat bertahan hidup apabila mereka tidak mengetahui dengan teliti pada musim apa berbagai jenis ikan pindah ke hulu sungai. Selain itu, manusia tidak dapat membuat alat apabila tidak mengetahui dengan teliti ciri bahan mentah yang mereka pakai untuk membuat alat tersebut.

Respons merupakan tanggapan individu dalam bentuk tingkah laku akibat rangsangan atau stimulus yang diterima. Pelatihan bencana dan keselamatan dalam penelitian ini berperan sebagai stimulus. Individu akan memberikan reaksi (respons) dengan hadirnya stimulus yang diterimanya. 
Pemahaman ini berarti bahwa respons tidak akan terjadi apabila tidak ada stimulus. Peran stimulus terhadap respons persepsi dapat dibedakan, dengan membandingkan nilai pengukuran pengetahuan dan sikap sebelum diberikan pelatihan (stimulus). Sebelum pelatihan mayoritas responden kurang memahami, hal ini disebabkan oleh karena responden belum mendapatkan informasi tentang manajemen bencana dan keselamatan. Responden yang memahami, sebelumnya pernah mendapatkan informasi dari sekolah (jenjang pendidikan) sebelum melanjutkan pendidikan ke program studi Ilmu Kesehatan Masyarakat.

Kuesioner yang digunakan untuk mengukur pengetahuan responden, pada beberapa item pertanyaan seperti: informasi dalam bentuk gambar bahan yang mudah meledak masih, bahan kimia berbahaya (yang dapat ditemukan pada label obat atau bahan kimia) mayoritas responden yang tidak mengetahui, demikian pula informasi pintu keluar jika ada bencana padahal gambar ini dapat ditemukan diindustri, mall, gedung bertingkat, maupun di tempat yang diindikasi mengandung gas. Responden juga seluruhnya tidak mengetahui kebutuhan pada saat terjadi bencana yang utama adalah alat komunikasi.

Item pertanyaan yang disajikan dalam kuesioner, merupakan tanda (rambu keselamatan) penting yang wajib diketahui oleh masyarakat luas, tanda bahaya tersebut banyak ditemukan di tempat umum. Namun seluruh responden tidak mengerti makna yang ada dari rambu tersebut. Meski tanda tersebut terdapat di tempat umum, apabila seseorang tidak mempunyai perhatian dan minat maka informasi tidak akan bisa diingat, disimpan dalam memory, dimengerti dan dipahami oleh seseorang.

Responden (mahasiswa) juga tidak mengetahui bahwa di Universitas Islam Negeri Sumatera Utara, kampus 1 Jalan IAIN dan Kampus II Jalan Willem Iskandar sudah ada rambu keselamatan seperti titik kumpul. Hal ini tidak sesuai dengan hasil observasi di lapangan. Artinya bahwa pengetahuan responden masih rendah terhadap rambu keselamatan di lingkungan kampus. Pemahaman seseorang bersumber dari informasi yang diperoleh melalui proses berfikir dan belajar. Pemahaman merupakan kemampuan untuk mengerti, diketahui dan diingat. Tolok ukur pemahaman seseorang adalah dapat: mempertahankan, membedakan, menduga, menerangkan, menafsirkan, memperkirakan, menentukan, memperluas, menyimpulkan, menganalisis, memberi contoh, menuliskan kembali, mengklasifikasikan dan mengihtiarkan (Al Hafizh, 2013).

Proses belajar mempunyai tingkatan, menurut taksonomi Bloom bahwa pemahaman mempunyai tingkatkan yang lebih tinggi dari sekedar mengetahui (tahu). Namun agar pengetahuan berada pada 
tingkat memahami, individu harus tahu (mengetahui) terlebih dahulu. Seseorang yang mempunyai pengetahuan belum tentu memahami sesuatu yang dimaksud secara mendalam, hanya sekedar mengetahui tanpa bisa menangkap makna dan arti dari sesuatu yang dipelajari. Pemahaman lebih mendalam yaitu, seseorang tidak hanya bisa menghapal sesuatu yang dipelajari, tetapi juga mempunyai kemampuan untuk menangkap makna dari sesuatu yang dipelajari juga mampu memahami konsep dari pelajaran tersebut.

Dukungan asumsi diatas sesuai dengan fakta hasil penelitian Damayanti dkk (2017) yang menguraikan bahwa hampir seluruhnya responden (85\%) sebanyak 28 orang memiliki tingkat pengetahuan yang baik tentang manajemen bencana. Setiap individu memiliki pengetahuan berbedabeda sesuai pengalaman dan informasi yang didapatkan bahwa ilmu pengetahuan dapat diterima dari berbagai sarana dan informasi sehingga pengetahuan tentang manajemen bencana dapat diterima oleh individu melalui informasi yang diperolehnya.

Selanjutnya pengukuran terhadap variabel sikap diketahui bahwa sebelum pelatihan, hasil pengukuran sikap kategori respons baik sebanyak 53,3\% dan responden yang kurang merespons sebanyak 46,7\%. Hasil penelitian ini sependapat dengan penelitian sebelumnya, bahwa sikap dipengaruhi oleh pengetahuan, karena pengetahuan siswa yang kurang tentang bencana, maka sikap responden juga tidak merespons (Sasikome, Jacklin Rifka; Lucky T. $\mathrm{Ku}, 2015)$. Pengetahuan yang diperoleh seseorang memengaruhi sikapnya dalam bertindak, sebagai contoh orang yang mengerti ada bahaya maka orang tersebut akan menjauhi sumber bahaya tersebut.

Proses perubahan sikap melalui tahap atensi, pemahaman dan penerimaan. Teori yang dikemukakannya adalah teori stimulus respon dan penguatan yang menyatakan bahwa proses perubahan sikap menunjukkan persamaan dengan proses belajar dan prinsip memiliki keterampilan verbal dan motorik juga dapat diterapkan dalam mengartikan pembentukan dan perubahan sikap (Zainuddin, 2017).

Sesuai dengan konsep perubahan sikap yang dikemukan oleh Kelley bahwa tahap perubahan sikap terjadi melalui proses:

1. Perhatian. Stimulus yang diberikan organisma dapat diterima atau ditolak. Jika ditolak proses selanjutnya terhenti. Sebaliknya apabila stimulus diterima berarti stimulus tersebut efektif dalam mempengaruhi organisme.

2. Pengertian. Apabila stimulus telah mendapatkan perhatian, maka proses selanjutnya adalah mengartikan stimulus tersebut. Kemampuan dalam tahap inilah yang dapat melanjutkan proses berikutnya. 
3. Penerimaan. Pada tahap ini individu menerima secara baik apa yang telah diolah sehingga adanya kesediaan untuk merubah sikap.

Mencermati konsep perubahan sikap menurut Kelley diatas dan hasil penelitian bahwa responden yang kurang merespons sebanyak 46,7\%, menunjukkan bahwa masih banyak responden yang tidak berespons positif terhadap bencana dan keselamatan kesehatan di lingkungan kampus. Teori ini secara implisit menekankan bahwa proses perubahan sikap melibatkan pengetahuan seseorang, namun diawali dengan perhatian. Perhatian ditentukan oleh suka atau tidak (minat) seseorang terhadap informasi yang diterima. Penjelasan ke 2 (pengertian) dari teori diatas, melibatkan persepsi. Setelah perhatian maka persepsi berperan didalam "memaknai" informasi yang diperoleh. Jika persepsi memaknai informasi secara positif, maka sikap akan menerima informasi tersebut.

Upaya peningkatan pengetahuan, dilakukan dengan berbagai cara seperti: memberikan informasi, himbauan, persuasi, bujukan, ajakan dan sebagainya. Penelitian ini menggunakan intervensi pelatihan, yang bertujuan untuk memengaruhi pengetahuan responden.

Pelatihan manajeman bencana dan keselamatan kesehatan memberikan pengaruh terhadap respons persepsi.
Pelatihan merupakan kegiatan jangka pendek yang dilakukan secara sistematis sebagai proses belajar untuk mencapai peningkatan pengetahuan, sikap, tindakan dan ketrampilan tertentu. Sumantri (2000) mengartikan pelatihan sebagai: "proses pendidikan jangka pendek yang menggunakan cara dan prosedur yang sistematis dan terorganisir. Para peserta pelatihan akan mempelajari pengetahuan dan keterampilan yang sifatnya praktis untuk tujuan tertentu" (Sumantri, 2000). Disimpulkan bahwa yang dimaksud dengan pelatihan adalah proses pendidikan dalam usaha meningkatkan kualitas dan kompetensi peserta pelatihan untuk masa sekarang dan akan datang, serta dilaksanakan dalam jangka pendek dengan cara praktis dan sistematis (Daud et al., 2014).

Tabel 8 Pengaruh Pelatihan Terhadap Respons Persepsi Pengetahuan

\begin{tabular}{llrccc}
\hline Variabel & Mean & SD & SE & Pvalue & N \\
\hline $\begin{array}{l}\text { Pengetahuan } \\
\text { Sebelum }\end{array}$ & 5,33 & 1,768 & 0,323 & & \\
$\begin{array}{l}\text { Pelatihan } \\
\text { Pengetahuan }\end{array}$ & 6,60 & 1,037 & 0,189 & & \\
$\begin{array}{l}\text { Setelah } \\
\text { pelatihan }\end{array}$ & & & & & \\
\hline
\end{tabular}

Langkah strategis yang dapat dilakukan untuk meningkatkan kesiapsiagaan siswa adalah dengan memberikan pelatihan tentang penanggulangan bencana. Pelatihan penanggulangan bencana memberdayakan siswa dengan memberikan keterampilan keselamatan dan hidup dasar yang 
diperlukan untuk aman "get safe" dan tetap aman "stay safe" selama bencana berlangsung sehingga siswa dapat terhindar dari dampak bencana alam gempa bumi, serta dapat melakukan pertolongan pertama pada korban dan cara evakuasinya apabila peristiwa gempa bumi terjadi pada saat jam sekolah (BNPB, 2012).

Menurut BNPB (2012) kegiatan pendidikan dan pelatihan kebencanaan di sekolah menjadi strategi efektif, dinamis, dan berkesinambungan dalam upaya penyebarluasan pendidikan kebencanaan. Kesiapsiagaan siswa setelah diberikan pelatihan penanggulangan bencana terjadi kenaikan pada kesiapsiagaan tingkat sedang $(60,0 \%)$ menjadi kesiapsiagaan tingkat tinggi sebanyak $(46,7 \%)$, dan penurunan pada kesiapsiagaan tingkat rendah sebanyak $(20,0 \%)$. Hal ini membuktikan bahwa setelah mendapatkan pelatihan penanggulangan bencana, terjadi peningkatan tingkat kesiapsiagaan siswa dalam menghadapi bencana gempa bumi (Nurudin, 2015).

Bencana tidak dapat diduga datangnya, mengancam kapan saja dan terjadi secara tiba-tiba. Manusia adalah hamba Allah yang sempurna diberi kemampuan untuk berfikir, termasuk juga timbulnya bencana. Analisa penyebab bencana dapat berupa; azab karena dosa yang dilakukan manusia, ujian dari Allah dan sunnatullah (proses alam). Hal ini dijelaskan dalam Al Quran surah Ar-Rum (41):

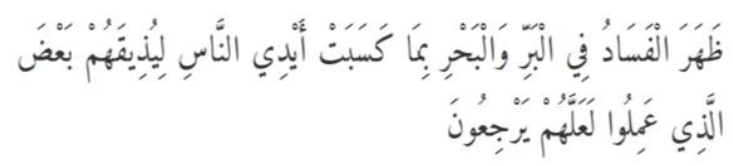

Artinya: "Telah tampak kerusakan di darat dan di laut disebabkan karena perbuatan tangan manusia, Allah menghendaki agar mereka merasakan sebagian dari (akibat) perbuatan mereka, agar mereka kembali (kejalan yang benar) QS Ar-Rum ayat 41).

Menurut sabir (2016) bahwa Gempa bumi, tsunami dan gunung meletus adalah murni bencana alam, dan bencana yang lainnya yang muncul dari alam seperti banjir, kekacauan iklim, tanah longsor merupakan bencana lingkungan hidup yang bukan pertama-tama dan terutama disebabkan oleh peristiwa alam, tetapi juga akibat adanya campur tangan manusia di dalamnya. Istilah bencana lingkungan hidup, menurutnya karena sebagian atau seluruh peristiwa tersebut disebabkan oleh krisis lingkungan hidup, yaitu kehancuran, kerusakan dan pencemaran lingkungan hidup akibat ulah dan perilaku manusia yang tidak mencintai alam (Sabir, 2016).

Tanpa disadari bencana terjadi karena perbuatan manusia, seperti merusak alam. Manusia telah lengah dan tidak menyadari perbuatannya. Ayat lain menyebutkan bahwa kebinasahan yang terjadi karena manusia lengah. 


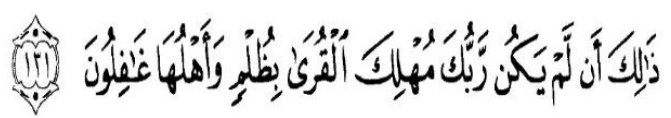

Manusia tidak boleh lengah, harus senantiasa waspada. Kewaspadaan dini terhadap bencana merupakan upaya manusia bertahan dan sunatullah untuk menjalani ujian Allah, memperbaiki diri, menjaga perilaku dan senantiasa berbuat kebaikan terhadap lingkungan (alam). Ikhtiar dan sikap optimis dianjurkan dalam islam. Ikhtiar yang dilakukan untuk persiapan menghadapi bencana adalah; bentuk pelatihan manajemen bencana dan keselamatan. Salah satu upaya untuk meminimalkan jumlah kecelakaan kerja adalah melalui pendidikan dan pelatihan (Endroyo et al., 2015)

Penanganan bencana pada dasarnya di tujukan sebagai upaya untuk meredam dampaknya dan memperkecil korban jiwa, kerusakan dan kerugian yang diakibatkan oleh bencana. Jadi penanganan bencana bukan mencegah untuk terjadinya melainkan mencegah dampak atau akibat yang ditimbulkan oleh bencana dan memperkecil korban jiwa, kerugian secara ekonomis dan kerusakannya. Sudah sejak lama masyarakat tradisional bisa mengantisipasi terjadinya bencana karena mereka mampu melakukan prediksi, previsi dan preservasi secara langsung (Sudrajat, 2015).
Tabel 9 Pengaruh Pelatihan Terhadap Respons Persepsi Sikap

\begin{tabular}{llllll}
\hline Variabel & Mean & SD & SE & P value & N \\
\hline $\begin{array}{l}\text { Sikap } \\
\text { Sebelum }\end{array}$ & 40,27 & 4,683 & 0,855 & & \\
$\begin{array}{l}\text { Pelatihan } \\
\text { Sikap }\end{array}$ & & & & 0,0001 & 30 \\
$\begin{array}{l}\text { Setelah } \\
\text { pelatihan }\end{array}$ & & & & & \\
\hline
\end{tabular}

Pengetahuan dan sikap tidak dapat dipisahkan. Kedua hal tersebut saling berhubungan, dengan adanya pengetahuan tentang kesiapsiagaan bencana gempa bumi maka akan mempengaruhi sikap seseorang saat terjadi bencana. Selain itu, sikap yang didasarkan pada pengetahuan akan dapat dimanfaatkan dalam jangka panjang (Daud, 2014).

Pemerintah dan masyarakat harus bersama melakukan penanggulangan bencana sehingga penanggulangan bencana dapat dilakukan secara efektif dan efisien. Tugas pemerintah melakukan penanggulangan bencana melalui tahap response, recovery dan development dimana didalamnya terdapat tindakan evakuasi, penyediaan kebutuhan dasar korban, upaya rekonstruksi dan rehabilitasi, serta perbaikan lain yang juga dimaksudkan sebagai langkah mitigasi bencana. Masyarakat dapat berpartisipasi dalam penanggulangan bencana melalui partisipasi buah pikiran, tenaga, harta benda, keterampilan dan kemahiran, serta partisipasi sosial (Nisa, 2014). 
Pencegahan kecelakaan perlu dilakukan di sekolah untuk meningkatkan pengetahuan, keterampilan, sikap, dan kebiasaan semua pihak yang terlibat. Tuntutan terhadap peningkatan kemampuan tersebut dapat memberikan kontribusi untuk mengurangi tingkat kecelakaan. Oleh karena itu sangat penting menerapkan pendidikan keselamatan maupun penerapan kurikulum di sekolah (Endroyo et al., 2015).

Beberapa penelitian sebelumnya menjelaskan bahwa pelatihan program pengurangan risiko bencana bertujuan untuk meningkatkan pengetahuan siswa terhadap bencana gempa bumi serta dampak yang ditimbulkannya. Kegiatan pelatihan para siswa juga diajarkan cara-cara mengantisipasi jika terjadinya bencana gempa bumi. Dengan kata lain, siswa secara aktif melakukan simulasi bencana gempa bumi selama proses pelatihan. Dari hasil di atas terlihat bahwa terdapat perbedaan antara nilai rerata hasil tes awal dan tes akhir siswa (Fajrizal; Kahiruddin; Nizam Ismail, 2016).

Hasil penelitian ini bertolak belakang dengan penelitian yang dilakukan oleh Widjanarko (2018) berjudul "Pengaruh pendidikan Bencana pada Perilaku Kesiapsiagaan Siswa" menyebutkan bahwa perbedaan skor pre test dan post test siswa setelah pelatihan sangat kecil. Hasil analisis uji t diperoleh nilai 0,059 lebih besar dari nilai $p$ value $(0,05)$ menunjukkan bahwa tidak ada pengaruh pendidikan bencana pada perilaku kesiapsiagaan siswa dalam menghadapi bencana. Penjelasan dari uji hipotesis yang tidak signifikan disebabkan oleh: Pertama, pelaksanaan pendidikan bencana tidak terjadwal dengan rutin sehingga subjek yang masih berada pada masa perkembangan (anak Sekolah Dasar kelas 5) tidak terbiasa, sering lupa dengan apa yang telah disampaikan dan diinformasikan dalam pelatihan. Kedua, subjek terkadang tidak ingat dalam berperilaku kesiapsiagaan menghadapi bencana karena pihak sekolah belum pernah melaksanakan kegiatan pendidikan kesiapsiagaan, dan pelatihan yang dilakukan pada saat penelitian merupakan yang pertama sekali diikuti oleh siswa tersebut (Widjanarko \& Minnafiah, 2018).

\section{Temuan Penelitian}

Hasil penelitian telah menjawab rumusan masalah penelitian. Beberapa temuan yang diperoleh dari penelitian ini antara lain:

1. Perubahan persepsi pengetahuan dan sikap dimulai dari pemahaman. Pemahaman diperoleh dari pengetahuan yang bersumber dari stimulus yang diterima. Kualitas stimulus menentukan pengetahuan seseorang, kualitas yang dimaksud adalah cara, metode, kompetensi trainer. Perbedaan dengan penelitian sebelumnya, tidak menjelaskan proses 
perubahan persepsi dan kualitas stimulus.

2. Perubahan persepsi sikap bergantung pada penerimaan individu terhadap stimulus yang diberikan. Individu mempunyai kecenderungan besar untuk menentukan, dan informasi akan diterima apabila individu: suka terhadap stimulus, kemudahan untuk mengerti informasi, ada minat dan perhatian, serta kebutuhan terhadap stimulus (sangat memerlukan). Berbeda dengan penelitian sebelumnya, membuktikan bahwa sikap dipengaruhi oleh pengetahuan tetapi tidak menjelaskan bahwa proses perubahan sikap.

3. Stimulus pelatihan membangun respons persepsi positif. Pelatihan bencana lebih efektif dan dapat diterima, apabila dikombinasikan dengan materi keselamatan dan kesehatan kerja di lingkungan kampus sehingga lebih mudah diterima oleh responden. Mengingat bahwa keselamatan dan kesehatan kerja merupakan bagian yang tidak terpisahkan dari kehidupan seharihari, bahkan rambu keselamatan dapat ditemukan ditempat umum, instansi, lembaga dan lain sebagainya. Perbedaan penelitian ini dengan penelitian sebelumnya, pelatihan yang diberikan (tidak dikombinasikan dengan K3).

\section{KESIMPULAN}

1. Modifikasi pelatihan manajemen bencana dan keselamatan kesehatan kerja lebih mudah dipahami oleh responden, sehingga efektif merubah pengetahuan dan sikap responden. Pemahaman mendorong seseorang untuk membentuk sikap positif yang dapat membentuk perilaku seseorang.

2. Keberhasilan pelatihan sebagai sarana merubah pengetahuan dan sikap, ditentukan oleh faktor internal dan ekternal. Faktor internal bersumber dari dalam dirinya sendiri seperti motivasi, persepsi, kemauan, kebutuhan dan suasana hati. Faktor eksternal bersumber dari luar dirinya seperti stimulus yang diterima, bentuk, warna, ukuran, keunikan dan sebagainya.

3. Penerapan Keselamatan dan Kesehatan Kerja pada tingkat Universitas dapat berjalan, jika ada komitmen bersama dari semua pihak sivitas akademi, baik pimpinan maupun pelaksanan.

4. Beberapa Universitas dan Kampus telah memulai penerapan keselamatan dan kesehatan kerja, namun belum sesuai dengan PP No 50 Tahun 2012 dan OHSAS 18001 yang menyebutkan bahwa kebijakan keselamatan dan kesehatan kerja harus dibuat secara 
tertulis dan ditandatangani agar diketahui dan dibaca oleh semua pihak.

\section{SARAN}

1. Setiap tempat kerja perusahaan, industri, instansi, lembaga pemerintahan/non pemerintah, dan tempat umum diharapkan, menerapkan sistem kewaspadaan bencana serta penerapan keselamatan dan kesehatan dengan memasang rambu keselamatan.

2. Responden hendaknya menerapkan serta menyebarluaskan informasi manajemen bencana dan keselamatan kesehatan kerja di lingkungan Universitas Islam Negeri Sumatera Utara Medan. Penerapan budaya keselamatan dan kesehatan dimulai dari lingkungan sekitar, rumah, sekolah dan tempat-tempat umum lainnya.

3. Universitas perlu meningkatkan sistem kewaspadaan bencana dan keselamatan dengan melakukan pengawasan kepatuhan sivitas akademi terhadap aturan dan tata tertib rambu keselamatan di lingkungan kampus.

\section{DAFTAR PUSTAKA}

Adriansyah, A. A. (2017). Keterkaitan Antara Sanitasi Pondok Pesantren dengan Kejadian Penyakit yang Dialami Santri di Pondok Pesantren Sunan Drajat. MTPH Journal, 1(1), $42-51$.

Afif, I. (2016). Rahasia di Balik Diciptakannya Manusia Berbeda-beda Suku dan Bangsa - Halhalal. Retrieved from http://www.halhalal.com/rahasiadi-balik-diciptakannya-manusiaberbeda-beda-suku-dan-bangsa/

Al Hafizh, M. (2013). Pengertian Pemahaman dalam Pembelajaran. Retrieved from http://www.referensimakalah.com/201 3/05/pengertian-pemahaman-dalampembelajaran.html

Atikah; Ida Wahyuni; Ekawati. (2016). Analisis Komitmen Pimpinan terhadap Kesiapan Penerapan Sistem Manajemen K3 pada Salah Satu Fakultas Kesehatan Masyarakat di Indonesia. Jurnal Kesehatan MAsyarakat, 4(4), 645-651.

Creswell., W. J. (2014). Research Design Pendekatan Kualitataif, Kuantitatif dan Mixed (Cetakan IV). Yogyakarta: Pustaka Pelajar.

Damayanti, D. P. W. R. M. (2017). Hubungan Pengetahuan tentang Manajemen Bencana dengan Prevention Masyarakat dalam Menghadapi Bencana Gunung Meletus pada Kepala Keluarga di RT 06/RW 01 Dusun Puncu Kecamatan Puncu Kediri. Jurnal Ilmu Kesehatan, 5(2), 115-127.

Daud, R., Sari, S. A., Milfayetty, S., \& Dirhamsyah, M. (2014). Penerapan Pelatihan Siaga Bencana dalam Meningkatkan Pengetahuan, Sikap, dan Tindakan Komunitas SMA Negeri 5 Banda Aceh. Jurnal Ilmu Kebencanaan (JIKA), 1(1), 26-34.

Endroyo, B., Yuwono, B. E., Mardapi, D., \& Soenarto. (2015). Model of learning/training of Occupational Safety \& Health (OSH) based on industry in the construction industry. Procedia Engineering, 125(December 2015), 83-88. https://doi.org/10.1016/j.proeng.2015. 11.013

Fajrizal; Kahiruddin; Nizam Ismail. (2016). PENGARUH PELATIHAN 
PROGRAM PENGURANGAN RISIKO DAN SIKAP SISWA SD NEGERI 3 TANGSE. Kedokteran Syiah Kuala, 16(2), 74-79.

Hastono, S. P. (2016). Analisis Data pada Bidang kesehatan (Cetakan 1). Jakarta: Rajawali Pres.

Hastono, S. P. D. D. M. (2016). Analisis Data Pada Bidang Kesehatan. Jakarta: PT Raja Grafindo Persada.

Herianto, R., Nulhaqim, S. A., \& Rachim, H. A. (2015). Community Based Disaster Management (pp. 326-330).

Jati, W. R. (2013). Analisis Penanggulangan Bencana Berbasis Perpektif Cultural Theory. Jurnal Penanggulangan Bencana, 4(1), 35-44. https://doi.org/ISSN: 2087 636X

Kurniawati, D. S. (2016). Pengaruh Pengetahuan Kebencanaan Terhadap Sikap Kesiapsiagaan dalam Menghadapi Bencana pada Mahasiswa Program Studi Pendidikan Geografi Universitas Kanjuruhan Malang. eJournal.unikama, 135-142. Retrieved from

ejornal.unikama.ac.id/index/php/JPIG/ issue/download/260/25

Mardiana, R. (2017). Keragaman Budaya dan Sikap Risma Mardiana. Jakarta: Tempo. Co.

Musa Wahyu Pangeran, Djoko Kustono, T. (2016). Faktor Yang Mempengaruhi Penerapan K3 di Bengkel Pemesinan. Jurnal Pendidikan Sains, 4(3), 90-94.

Noor, J. D. S. . (2013). Metodologi Penelitian. Jakarta: Kencana Prenada Media Group.

Notoatmodjo, S. (2003). Ilmu Kesehatan Masyarakat. Jakarta: Rineka Cipta.

Notoatmodjo, S. (2007). Promosi Kesehatan dan Ilmu Perilaku. Jakarta: Rineka Cipta.

Nur, A. (2014). Pengaruh Usia, Tingkat Pendidikan, dan Jenis Kelamin terhadap perilaku Konsumsi Media. Skripsi. Semarang: Fakulta sILmu Sosial dan Politik Universitas Diponegoro.

Nurudin, A. (2015). Pengaruh Pelatihan Penanggulangan Bencana Gempa Bumi Terhadap Kesiapsiagaan Siswa Kelas Vii Di Smp Negeri 1 Imogiri Bantul Yogyakarta.

Putra, H. P., \& Aditya, R. (2014). Pelatihan mitigasi bencana kepada anak-anak usia dini. Jurnal Inovasi Dan Kewirausahaan, 3(2), 115-119.

Ramadhan, A. (2013). Kategori Umur Menurut Depkes RI. 17 Januari. Retrieved from https://arfkomunika.blogspot.co.id/201 4/01/kategori-umur-menurut-depkesri-2009.html

Riyanto, A. (2010). Basic Data Analysis for Health Research Training. Pengolahan dan Analisis Data Kesehatan. Medan: Sekolah Tinggi Ilmu Kesehatan Rumah Sakit Haji Medan.

Rudianto. (2012). Komunikasi dalam Penanggulangan Bencana. Ilmu Komunikasi.

Sabir, A. M. P. (2016). Gambaran Umum Persepsi Masyarakat Terhadap Bencana. Jurnal Ilmu Ekonomi Dan Sosial, 5(3), 304-326. Retrieved from https://media.neliti.com/media/publica tions/237547-gambaran-umumpersepsi-masyarakat-terhad501404e6.pdf

Sandy, W. (2012). Tingkat pengetahuan tentang keselamatan pada siswa sekolah dasar skripsi.

Sasikome, Jacklin Rifka; Lucky T. Ku, aat; M. (2015). PENGARUH PENYULUHAN BENCANA BANJIR TERHADAP KESIAPSIAGAAN SISWA SMP KATOLIK SOEGIYO PRANOTO MANADO MENGHADAPI BANJIR.

Satria. (2015). Universitas Gadjah Mada 
Mengedepankan Keselamatan, Kesehatan dan Lingkungan. Yogyakarta. Retrieved from https://ugm.ac.id/.../9868-

program.k3.turunkan.angka.kecelakaa n.kerja.petani.sawah?...\%0A\%0A

Setyaji, W. (2013). Implementasi Keselamatan dan Kesehatan Kerja di Kampus UI Depok yang Belum Maksimal. Jakarta. Retrieved from http://wildansetyaji.blogspot.com/201 3/03/implementasi-keselamatan-dankesehatan.html

Sitepu, H. K., \& Tambunan, M. M. (2014). Identifikasi Tingkat Bahaya Di Laboratorium Perguruan Tinggi ( Studi Kasus) Laboratorium Di Lingkungan Departemen Teknik Industri Universitas Sumatera, 47-52.

Sudrajat, S. W. (2015). PEMAHAMAN TENTANG MENEJEMEN BENCANA ALAM SISWA SEKOLAH MENENGAH PERTAMA, 168-189.

Sumantri, S. (2000). Pelatihan dan Pengembangan Sumber Daya Manusia. Bandung: Fakultas Psikologi UNPAD.

TB A. (2015). PERKEMBANGAN KEPRIBADIAN REMAJA. Jawa Timur: TB-A STAIN PONOROGO.

WHO. (2015). World Health Statistic. Geneva Switzerland.

Widjanarko, M., \& Minnafiah, U. (2018). Pengaruh pendidikan bencana pada perilaku kesiapsiagaan siswa. Jurnal Ecopsy, 5(1), 1-7. Retrieved from https://www.researchgate.net/publicati on/325948325_PENGARUH_PENDI DIKAN_BENCANA_PADA_PERIL AKU_KESIAPSIAGAAN_SISWA

Wulansari, Diah; Darumurti, Awang; Eldo, D. H. A. P. (2017). Pengembangan Sumber Daya Manusia dalam Manajemen Bencana. Journal of Governance And Public Policy, 4(3), $1-15$. https://doi.org/https://doi.org/10.18196 /jgpp.4383

Zainuddin, A. (2017). Perubahan Sikap Makalah Ahli. Retrieved from https://makalahahli.blogspot.com/2017 /09/perubahan-sikap.html 